Journal of

Dentistry and Oral Health

\title{
Workplace Harassment: The Acumen of a Submissive Fact in Dentistry
}

\section{Mythri Halappa*}

Department of Public Health Dentistry, Sri Siddhartha Dental College, Tumkur, India

${ }^{\star}$ Corresponding author: Mythri Halappa, Department of Public Health Dentistry, Sri Siddhartha Dental College, Tumkur, India; E-mail: drmythripcd@gmail.com

Received Date: January 03, 2019; Accepted Date: February 11, 2019; Published Date: February 13, 2019

Citation: Mythri Halappa (2019) Workplace Harassment: The Acumen of a Submissive Fact in Dentistry. J Dent Oral Health 5: $1-5$.

\begin{abstract}
The structure of the dental profession provides unique opportunities for both women and men to exercise a high degree of autonomy and flexibility and at the same time, enjoy the status awards associated with being a healthcare provider. Hence, dentists too encounter numerous sources of professional stress, beginning from the dental college. This stress can have a negative impact on their personal and professional lives. Of all workplace stress; bullying and harassment create a special danger as they operate destructively affecting the person's physical and mental wellbeing. Hence, this review is to give an insight about the workplace harassment, its short and long term deleterious effects\& the legal aspects.
\end{abstract}

Keywords: Work Place Harassment, Sexual Harassment, General Harassment, Bullying, Mental Health, Dentistry

\section{Workplace Harassment: The Acumen of A Submissive Fact In Dentistry}

With the crumbling economy, slashing jobs, and sinking home values, world has become more competitive. We live in an increasingly complex world where work weeks seem to be getting longer, not shorter. This struggle to survive and succeed leads to enormous occupational stress in life [1,2]. A survey in India has reported $48 \%$ of people have experienced workplace harassment or other [3].

\section{Challenges in Dentistry}

Dentistry is a profession dominated by men, but over the last 40 years the proportion of women is increasing steadily raising the question about the effect of feminization in this profession [3,4]. Workplace gender discrimination is illegal in several countries, it is prohibited by Civil Rights Act and was also addressed in academic settings [5-7]. Still, research during past 20 years overall in the world have revealed sexual harassment being widespread in general society and in higher education, health profession education, and dental education

(C)2019 The Authors. Published by the JScholar under the terms of the Creative Commons Attribution License http://creativecommons.org/licenses/by/3.0/, which loize.marechal@umontreal.ca

maximilien.laviolette-brassard@umontreal.ca
[4, 8-14]. Dentists are prone to professional burnout, anxiety disorders and clinical depression, owing to the nature of clinical practice and the personality traits common among those who decide to pursue careers in dentistry [12].

\section{Workplace Environment}

Job stress is often confused with job challenge, but these concepts are not the same. Challenge energizes people psychologically and physically, and it motivates to learn new skills and master the jobs. Challenge is an important ingredient for healthy and productive work [11]. When a challenge is successfully met, people feel relaxed and satisfied. Hence a little stress is essential to reach the goal. If stress exceeds, it is devastating \& unbearable [1].

To be specific, workplace stress is the harmful physical and emotional response which occurs when there is a poor match between job demands and the capabilities, resources, or needs of the employees [12]. Of all the stressors working in an individual's life, job stress is one of the leading stressor. Initially, job stress vary from mild irritability, mood changes and short temper to extreme measures like committing suicide [1]. 


\section{Factors Leading to Job Stress}

Work place conditions leading to stress are [1],

1. Design of the tasks

One person works to the point of exhaustion; another is tied to the computer, allowing little room for flexibility.

2. Management style

Lack of participation by workers in decision-making, poor communication in the organization, and lack of family-friendly policies would all indicate a need to work on a more effective management style.

3. Interpersonal relationships

Lack of healthy relationship between employemployer, among coworkers can lead to friction in the working atmosphere.

4. Work roles

No clear role specification by the employer/head of the task can lead to mismatch in the expectations with that of job fulfillment.

5. Career concerns Instability with the career or the profession can lead to internal competition leaving a room for insecurity.

6. Environmental conditions

High demanding work atmosphere creates a more stress compared to friendly working conditions.

7. Salaries \& Wages

Financial balance with the work is very much required for the one to work. More work and less pay will lead to dissatisfaction causing stress.

8. Social change

Acceptance among the society due to many internal conflicts can also be a source of stress in this changing social environment.

A study has stated occupation-related stressors are based on two dimensions: Task or organization and interpersonal relations [9]. Burnout is defined by three coexisting characteristics-exhaustion mentally or emotionally, depersonalization or dehumanization, and dissatisfaction with their accomplishments and to evaluate themselves negatively [13-16]. Along with all these factors, harassment of any kind enhances the stress further.

\section{Harassment}

Harassment is any improper and unwelcome conduct reasonably expected or is perceived to cause offense or humiliation to another person. Harassment may take the form of words, gestures or actions which tend to annoy, alarm, abuse, demean, intimidate, belittle, humiliate or embarrass another or which create an intimidating, hostile or offensive work environment [17].

Workplace harassment encompasses varied forms of discrimination or interpersonal mistreatment arising from different sources in the workplace (e.g., co-workers, supervisors, customers) and is experienced through direct or passive offenses to the targets. Although definitions of harassment vary, typical explanations refer to offensive behaviors that are unsolicited and unwelcome [18].

\section{Types of Harassment}

Though Indian law speaks significantly about sexual harassment at the workplace, harassment against the employees is not restricted to the sexual alone [9]. There are various categories covered under the purview of harassment at the workplace against the employees due to which the workers have to suffer humiliation, often exploited by their respective supervisors or colleagues.

So, harassment at workplace can be differentiated into various dimensions which are as follows [9]:

\section{Sexual Harassment and General (Non- Sexual) Harassment}

Majority of the people believe in the common notion that harassment at workplace can be sexual harassment only. But this is not the case as the following different types can be categorized under general (non-sexual) harassment.

a. Harassment on the basis of- race, sex, religion and national origin.

b. Harassment based on age.

c. Harassment based on disability.

d. Defamation- To defame is to damage the reputation or image of the person

e. Criminal/Background history- An employee may be harassed for his/her previous criminal/past record, whose penalty he/she has already suffered.

f. Harassment due to different political beliefs- Though minor issue but can lead to harassment of the employee by the employer or fellow employees.

g. Sexual orientation and marital status.

h. Stalking.

Examples include leaving repeated or alarming messages on voice mail or e-mail, following people home, or approaching co-workers to ask for personal information.

k. Hostile workplace harassment.

1. Bullying by the supervisor. 


\section{Sexual Harassment}

Sexual harassment is an unwelcome deliberate or unintentional action creating a hostile work environment for the employee. Sexual harassment involves the interpretation of a verbal, nonverbal, or physical action against another person and may refer to an action not mutually agreed upon or reciprocated by another individual. This behavior interferes with an individual's work performance and creates an atmosphere of intimidation resulting in a lack of concentration for the victim [4].

\section{General Harassment}

Generalized harassment has been studied under various labels which differ in emphasis on aspects of the behaviors in question (i.e., duration, motivation, or power differences). These encompass verbal aggression, disrespectful or exclusionary behavior, isolation/exclusion, threats or bribes, and physical aggression, without explicit reference to duration of experiences, perpetrator motivation, or the power relationship between perpetrator and target and that are not obviously related to legally protected characteristics (e.g., gender, race/ethnicity, age, disability). Prevalence rates of nonsexual hostile workplace behaviors have been found to be $30 \%$ or higher for men and 55\% or higher for women [7].

Workplace harassment remains a salient workplace problem for all irrespective of the genders.

\section{Difference Between Bullying and Harassment}

A data on American related to workplace bullying in 2010 found 35\% experience bullying firsthand, $62 \%$ bullies are men; $58 \%$ targets are women, women bullies target women in $80 \%$ of the cases, $62 \%$ of bullies are same as gender harassment [19].

General harassment is often confused with bullying according to US legal, the definition of bullying is an intentional act causing harm to others. This can include verbal or non-verbal threats, taunts, physical attacks, blackmail, manipulation, or even extortion. An imbalance of power usually exists between the bully and the victim [17]. Bullies may feel jealous and possess a need to control people.

Harassment - US Legal defines harassment as conduct which annoys, threatens, intimidates, or causes fear in another person. It is unwanted behavior offends, demeans, or threatens another person. Power imbalance need not be present in harassment. The behavior causes a hostile environment. It includes derogatory comments, slurs, improper propositions, assault, separating the person and visual insult. There is no hierarchical discrimination in harassment, even the juniors can harass the seniors. This leads to physically impeding or performance blocking behavior by the victim where they try to distance themselves from distressing stimulus [20].

While these two definitions may sound very similar, how the law deals with them is very different.

There are two key differences between bullying and harassment $[17,18]$ :

The first difference is the reason for the behavior. Workplace harassment of any kind targets individuals or groups based on their belonging to a protected class like gender, race, ethnicity or a caste without hierarchy. For a workplace bully, who or what the person is may be arbitrary, but a power imbalance exists.

1. Second, victims of harassment have an external agency where complaints can be raised to if it's related to gender. Victims of bullying \& general harassment can just report to the committee in the institute.

\section{Legal Aspects Related to Harassment in India:} [21]

When harassment is based on person's race, color, national origin, sex, disability, or religion it is considered a violation of the person's civil rights [15].

Indian labor laws cover many acts under its purview. Since labor laws are covered under the concurrent list of the Seventh Schedule of the Constitution of India, both central and state governments have jurisdiction to pass their own laws on relations between the laborer's and relating to issues of the employment.

\section{A. Laws for harassment done by employer deducting unreasonable wages of employee}

Payment of Wages Act, 1936 is intended to be a remedy against the unreasonable and unauthorized deductions made by the 'Employer' or unjustified delay in payment of wages. Section 5 of the Act specifies the Time of payment of wages Timely payment of wages should be made. If manpower is less than 1000 workers, then 7 th day of the month and if more than 1000 , then 10th day of the month salaries should be given.

Section 7-13 defines the Deductions - No unreasonable and unauthorized deductions should be made from the wages of the employee by the employer. 
Employees can be harassed by not following the Principle of Equal Pay for Equal Work. According to Article 39(d) of the Constitution and Section 2(h) of the Equal Remuneration Act 1976 it is the duty of the employer that every employee should receive same remuneration for similar nature of work.

\section{B. Laws for harassment by sex discrimination}

The sexual harassment of women at workplace is a serious offense across the globe \& has legal implications everywhere. In India, it is covered by Indian Penal code, section 354 (Prevention, Prohibition \& Redressal) Criminal Act 2013 where penalties range from one to three years imprisonment and/ or a fine.

\section{Laws for harassment by defamation}

Section 499 of the Indian Penal Code defines the Defamation if it is a Criminal Wrong. Otherwise in civil cases defamation can be included under the Law of Torts.

D. Laws for harassment by unreasonable clauses in the employment agreements

Dismissal Regulation; Industrial Disputes Act 1947; Chapter 5A: Lay off and Retrenchment clearly states a 30 to 90-day notice period applies to terminate 'workmen' (employees whose role is not primarily supervisory, administrative or managerial) for convenience.

\section{E. Laws for discrimination on grounds of pregnancy and disability}

According to Maternity Benefit Act, 1961 it is unlawful and unauthorized on the part of the employer to discharge or dismiss women when she absents herself from work within the provision of this act.

Section 24A of the Persons with Disabilities (Equal Opportunities, Protection of Rights and Full Participation) Act of 1995 guarantees no discrimination in employment.

Currently there are no laws against bullying, whereas sexual harassment or harassment related to caste/ creed/ race/ ethnicity are punishable. But general harassment which can also be done by subordinates comes under neither bullying (as it is not in higher ranking hierarchy) nor harassment with specific reason (discriminatory harassment) hence escapes from the law.

To enjoy satisfying professional and personal lives, dentists must be aware of the large part of effective practice management is to understand the sources and implications of stress, and tackling it in an effective manner.

\section{Measures to be Taken at Workplace}

A dental institution or office should have an office policy where the definitions are clearly defined along with the job role/description of employees and they were made aware of the same.

A friendly atmosphere along with teamwork spirit to achieve institutional target lies in an effective management skill by a head / team leader. Transparent communication with the employee builds strength of the institution.

To facilitate a gender-sensitive and congenial working environment at dental colleges, so women at the work place are not subjected to gender specific discrimination or sexual harassment, along with a woman's grievances and Empowerment cell should be formed.

A general committee for grievances with nonbiased people should be formed where the employees can approach during time of need without any hesitation.

\section{Conclusion}

Of all workplace safety issues, bullying and harassment create a special danger because they operate so destructively in a cloud of conflicting perceptions about how human beings perform at work.

Both sexual \& general harassments negatively influence various mental health outcomes such as depression, anxiety, hostility, alcohol and drug use. Hence, the entire structure of justice needs transformation giving equal importance to overcome general harassments along with sexual harassments which remain always submissive. 


\section{Reference}

1) Mamatha J, Reetika B, Mathur T N. (2012) Work place stress \& suicide: a study with reference to public sector organisation. Int J Multidis App 2:186 -97.

2. Stress at work. Available from: www.cdc.gov/niosh/ stresswk.html. Cited on 06/08/2017.

3. Julia C M, Carlos Q. (2012) The feminization of dentistry: Implications for the profession. J Can Dent Assoc 78:c1.

4. Garbin C A S, Zina L G, Garbin A J I, Moimaz S A S. (2010) Sexual harassment in dentistry: prevalence in dental school. J Appl Oral Sci. 8:447-452.

5. Fiske ST, Glick P. (1995) Ambivalence and stereotypes cause sexual harassment: A theory with implications for organizational change. J Soc Iss. 51:97-115.

6. Nora LM. (1996) Sexual harassment in medical education: a review of the literature with comments from the law. Acad Med.71:S113-8.

7. Richman JA, Rospenda KM, Nawym SJ, Flaherty JA, Fendrich M, Drum ML, et al. (1999) Sexual harassment and generalized workplace abuse among university employees: prevalence and mental health correlates. Am J Public Health. 89:358-63.

8. SK Pallavi, Rajkumar G C. (2011) Professional practice among woman dentist. J Int Soc Prev Community Dent. $1: 4-19$.

9. Sfikas PM. (2005) Sexual harassment and vicarious liability. J Am Dent Assoc. 136:809-11.

10. Sfikas PM. (2004) Who's liable when an employee quits because of sexual harassment? Supreme Court to rule on employers' liability for supervisors' conduct. J Am Dent Assoc. 135:657-60.

11. Bejerot E. (2017) Dentistry in Sweden- Healthy work or ruthless efficiency? Available from: https://www.lunduniversity.lu.se Cited on 16/09/2017.

12. Rada RE, Johnson-Leong C. (2004) Stress, burnout, anxiety and depression among dentists. J Am Dent Assoc. 135:788-94.

13. Weinstein BD. (1994) Sexual harassment: identifying it in dentistry. J Am Dent Assoc.125:1016-21.

14. Wolf TM, Scurria PL, Bruno AB, Butler JA. (1992) Perceived mistreatment of graduating dental students: a retrospective study. J Dent Educ. 56:312-6.
15. Rajoura OP, Kumari A, Srivastava S. (2012) Sexual harassment and mental Health. Delhi Psychiatry Journal. 15:50-3.

16. Candice A, Shannon MA, Kathleen M R, Judith A R. (2007) Workplace harassment patterning, gender, and utilization of professional services: findings from a US National Study. Soc Sci Med. 64:1178-91.

17. Bullying and Harassment. Available from: https:// nobullying.com/harassment-and-bullying-is-there-a-difference/ Cited on 10/01/2018.

18. Differences between Bullying and Harassment. (2018) Available from: https://www.helioshr.com/2014/11/ key-differences-between-workplace-bullying-versus-harrassment/. Cited on 10/01/2018.

19. Work place bullying in the Dental profession. (2018) Available from: https://www.Workplace\%20bullying\%20 in $\% 20$ the $\% 20$ dental\%20profession $\% 20-\% 20$ Bite $\% 20$ Magazine.html. Cited on 12/03/2018.

20. Kothari N. Bullying in the dental profession. (2018) Available from: Bullying in the dental profession - Dentistry. co.uk. Cited on 10/04/2018.

21. Workplace harassment laws in India. (2018) Available from: http://employment.findlaw.com/employment-discrimination/understanding-different-types-of-harassment. html. Cited on 09/04/2018.

Submit your manuscript to a JScholar journal and benefit from:

ฯ Convenient online submission

ฯ Rigorous peer review

9 Immediate publication on acceptance

- Open access: articles freely available online

q High visibility within the field

- Better discount for your subsequent articles Submit your manuscript at http://www.jscholaronline.org/submit-manuscript.php 